\title{
Flood Events in Gangapur Village, Banke District: An Example of Climate Change-induced Disaster in Nepal
}

\author{
Tara Nidhi Bhattarai \\ Department of Geology, Tri-Chandra Campus \\ Tribhuvan University, Ghantaghar, Kathmandu \\ E-mail:tnbhattarai@wlink.com.np
}

\begin{abstract}
Climate change impacts in Nepal have resulted, among others, localized downpour which may trigger severe flooding and associated disasters in some parts of the country, particularly in the southern slope of the Siwalik. The purpose of this investigation was to evaluate the consequences of climate change impacts in the Dhondra River watershed that covers southern slope of the Siwalik and northern part of the Terai plane in Banke district, western Nepal. For the purpose, a field investigation was carried out and it indicated that Ward Nos. 5 and 6 of Gangapur Village Development Committee (VDC) were inundated in 2000 due to the blockade of the Singhya River by the deposition of flood-driven sediments brought by the Dhondra River. Consequently, about 305 families were completely displaced due to the inundation in and around their home and farmlands. The flood was resulted due to a localized torrential rainfall in Dhondra River's upper reaches in the Siwalik area. Following the year 2000, the Dhondra River started depositing sandy sediments in and around the confluence point with the Singhya River during each monsoon seasons. This paper briefly summarizes the causes of the disaster and its consequences to the displaced people, and surrounding geo-environment.
\end{abstract}

Key words: Climate Change, Disasters, Dhondra River, Siwalik, Singhya River

\section{INTRODUCTION}

The physiographic zone of Nepal is divided into the Terai, the Siwalik (Churia), the Middle Mountain, the High Mountain and the High Himal, from south to north, respectively (LRMP, 1986). The general topography is such that it forms almost flat ground in the Terai (along Indo-Nepal boarder), and elevation goes on increasing towards north resulting into steep mountain slopes, deep gorges, river valleys, and mighty snow peaks (along Nepal-China boarder). In terms of geological setting, Nepal is sub-divided in to five tectonic zones, namely the Indo-Gangatic Plain, the Siwaliks, the Lesser Himalaya, the Higher Himalaya and the Tibetan-Tethys zone, from south to north, respectively (Gansser, 1964). Each of these geologic units are demarcated by geological fault structures, which are responsible for on-going mountain building process caused by the collision of Indian Plate with Asian Plate. These tectonic units roughly correspond to the physiographic and ecologic zones and are extended in east-west direction throughout the country forming distinct zone of diverse climate, elevation, vegetation, and rock types. Because of the climatic, geologic and ecologic heterogeneity, as indicated in Table 1, particularly in the north south direction, the impact of climate change also differs.

Nepal is vulnerable for various types of natural hazards such as earthquake, flood, landslide and debris flows due to steep topography, on-going Mountain building processes, highly fractured rocks, diverse climate and intense precipitation. Along with these factors, the impact of climate change has further aggravated the domains of natural hazards as the extreme climatic events like shortlived torrential rainfall, localized intense precipitation, and prolonged drought, all are considered to be a part of the climate change impact are in increasing trend (Bhattarai, 2012). Generally, rapid glacial melting, which may lead Glacial Lake Outburst Floods (GLOF), forms the major climate change impact in the Tibetan Tethys zone and some parts of the Higher Himalayan zone. In Lesser Himalayan zone, landslides and drought are major climate induced hazard. The Siwalik zone is seriously affected by landslides, debris flows, and rill erosion whereas the Terai region is more prone to flood hazards along with sediment deposition at some places and river bank cutting at other places (Devkota \& Bhattarai, 2011).

As already mentioned above, impacts of climate change have significantly resulted, among others, localized downpour which may trigger severe flooding and associated disasters, particularly in the southern slope of Siwalik and it's down slope due to fragile rock exposures and loose nature of the sediment. The purpose of this investigation was to evaluate the consequences of climate change impacts in the Dhondra River watershed that covers southern slope of the Siwalik and northern 
part of the Terai in Banke district, western Nepal.

\section{MATERIALS AND METHODS}

The investigated site belongs to the Gangapur Village Development Committee (VDC), Banke district, Bheri Zone, western Nepal (Fig. 1). The maximum and minimum elevations of the area (Gangapur VDC) are $432.9 \mathrm{~m}$ and $138.2 \mathrm{~m}$, respectively. The area is accessible from Nepalganj, district head-quarter, with a graveled road connected with a few earthen roads. But during rainy seasons, the area becomes inaccessible due to the lack of bridges.

Since geology, climate, land use, and river dynamics play important roles in triggering sediment disaster and flood hazards (Joshi et. al. 1998), these factors were analyzed based on field investigation and literature review. The geological investigation was limited to observation of some locations within the lower and middle reaches of the Dhondra River watershed. It mainly covered the Siwalik (also known as the Churiya hills) and parts of the Terai plain to the south.

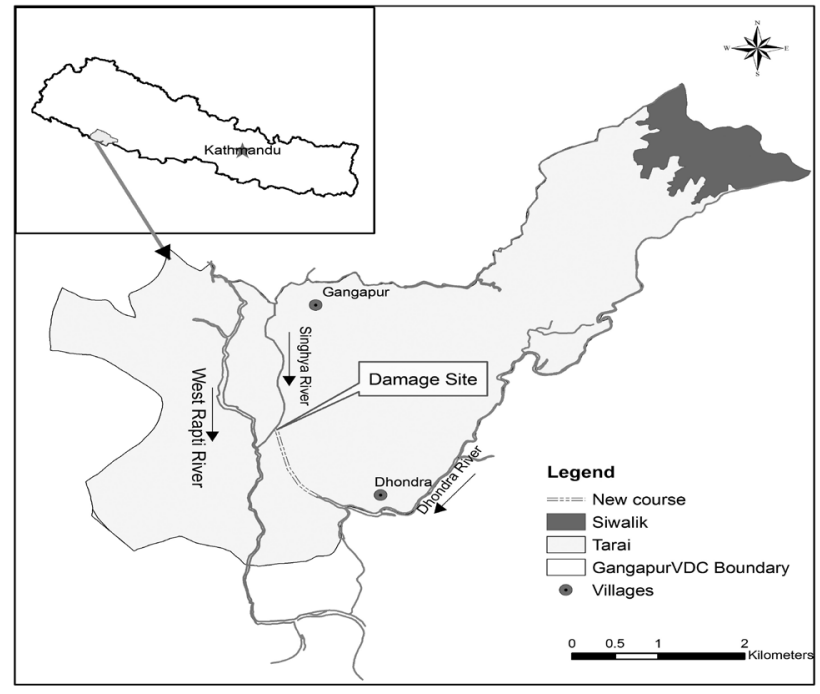

Fig. 1. Location map of the investigated area (Gangapur VDC) with the geological boundaries

In order to understand the state of climate change, an analysis of temperature trends was conducted on the basis of the data recorded at Nepalgunj regional office station (Station ID: 416) from 1976 to 2009. The station lies at an altitude of about $144 \mathrm{~m}$ above mean sea level (amsl) in the Terai plain, and it is the nearest station from the study site. In addition to temperature trends, an estimation of precipitation was also conducted on the basis of data recorded at the nearest station (Station: Bajiapur, Station ID: 414, Latitude: 2803', Longitude: 81054', Elevation:
$226 \mathrm{~m}$ ) located about $15.5 \mathrm{~km}$ away from the disaster site. The data covers from 1976 to 2012 (but data are not available for the years 2001 and 2007). The temperature and precipitation data were obtained from the Department of Hydrology and Meteorology, Government of Nepal.

Attempt was made to understand the river dynamics on the basis of longitudinal section of the river channel, and also the rock and soil types along the river. Information related to the land use, damage description, past flood events, and the geo-environment degradation was collected as per the field evidences and stakeholders' views.

\section{RESULTS}

\section{Geology}

The Siwalik range in the area is composed of sedimentary rocks namely, shale, sandstone and conglomerate. These rocks are highly jointed, and are easy to weather. A thrust fault, known as the Himalayan Frontal Thrust (HFT), forms the boundary between the Siwalik and the Terai plane. The Terai is subdivided into Bhaber Zone, Middle Terai and Southern Terai based on the nature of the sediments laid down in the area (Sharma, 1990). Generally, coarser materials (mainly boulders and gravels) are found in the Bhabar Zone, at the foothill of the Siwalik. Just to the south of Bhabar zone is the Middle Terai where sediments like gravels and sands are predominant. The Southern Terai is located to the south of the Middle Terai and the sediments are composed mainly of silt and clay. The sediments in the Terai consist of about $1500 \mathrm{~m}$ thick alluvium underlain by Siwalik rocks (Upreti, 2001). The investigated flood-affected area covers a part of the Bhabar Zone and a part of the Middle Terai.

The field investigation revealed a fact that the Dhondra River bed is not a smooth surface as there are rock exposures across the river bed (Fig. 2). The bedding of the rock exposures (mainly sandstone) dips due south with an angle that varies between 25 and 45 degrees. Out of three prominent set of joints, one set dips parallel to river flow direction (south) with an amount that ranges from 30 to 55 degrees. These rock exposures have formed low-lying (less than a meter in height in average) dams or barriers at several locations across the river. These barriers have behaved like natural check dams, which catch sediments and reduce river velocity. The width of the Dhondra River is a narrow one within the Siwalik range but it is deep enough to transport all the water even during flood events. But in the Terai region, it is shallow and high discharge is often spilled out as flood water. 


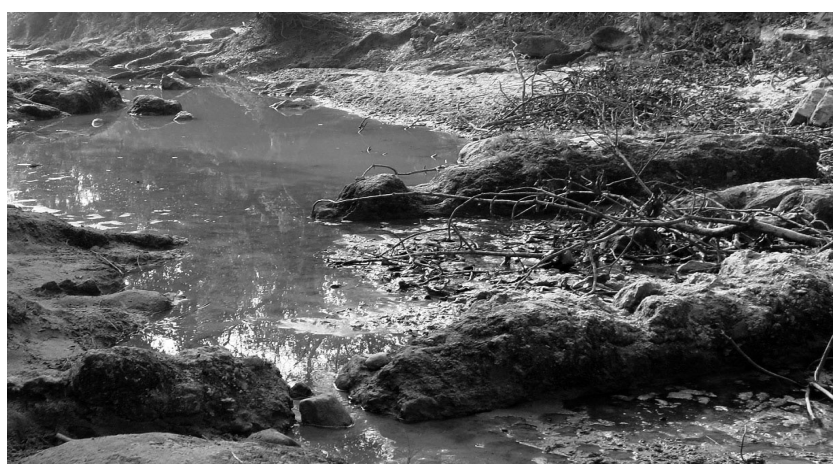

Fig. 2. Bed rock (mainly sandstone) behaves like natural check dams as it is exposed across the Dhondra River

\section{Temperature trend}

The temperature data were used to conduct the following analysis.

i) The average maximum, minimum and mean temperature for the years 1976 - 2009 (Fig. 3);

ii) The trend of annual maximum, minimum and mean temperature (Fig.4);

iii) The decade-wise (1976 to 1985,1986 to 1995 , and 1996 to 2009) annual trends for maximum, minimum and mean temperatures (Fig. 5); and

iv) Seasonal trends of maximum and minimum temperature variations (Fig.6a to 6d).

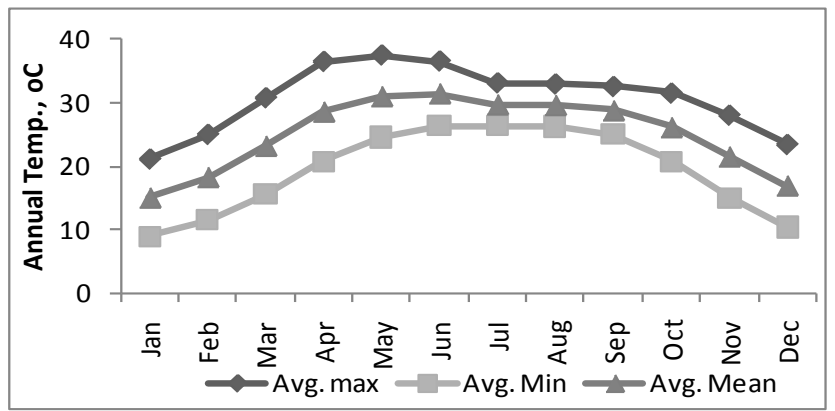

Fig. 3. Average monthly temperature trends for the period of 1976-2009

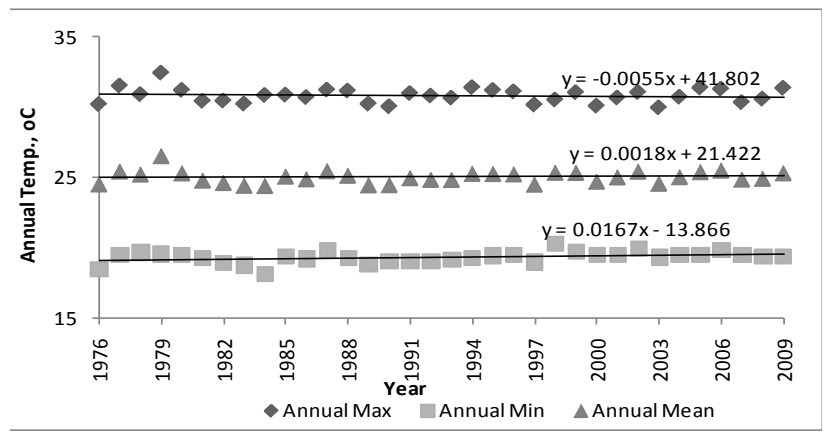

Fig. 4. Average annual trend of temperature for the period of 1976 - 2009

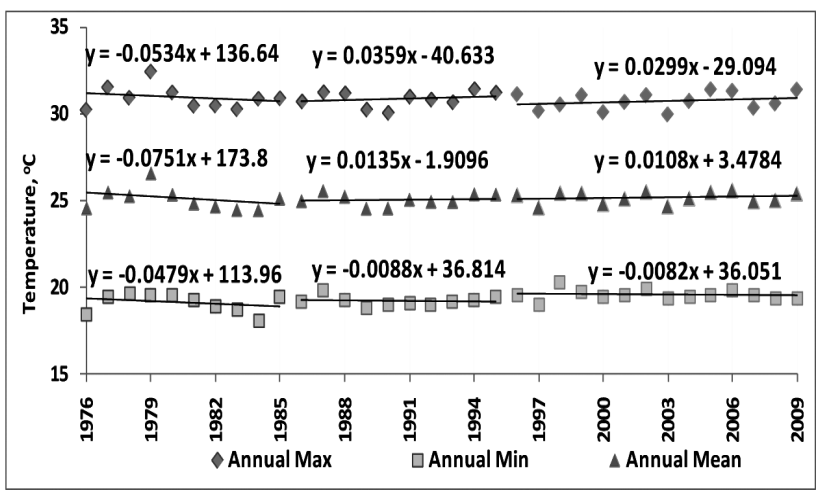

Fig. 5. Decadal trends in maximum, minimum and mean temperatures for the years 1976 - 2009

Based on the data of the 33 years (1976-2009), the highest average monthly temperature is observed during the month of May with an average value of about $38{ }^{\circ} \mathrm{C}$, whereas the lowest temperature is observed during the month of January with a monthly average value of about $8{ }^{\circ} \mathrm{C}$ (Fig. 3 ). In case of annual trend, although there does not exist any significant trend, it seems that the annual maximum temperature is on a very slight decreasing trend with a decline of $0.005{ }^{\circ} \mathrm{C}$ per year and the annual minimum temperature is gradually increasing with a trend of about $0.016{ }^{\circ} \mathrm{C}$ per annum (Fig. 4).

The decade wide trend analysis indicates that the maximum temperature is on a declining trend during 1976 - 1985. But after 1986 it follows an increasing trend with an average increment of $0.032{ }^{\circ} \mathrm{C}$ per year till 2009 (Fig.5). Similarly, minimum temperature follows an overall decreasing trend. However, the rate of decline is slightly less in the second and third decades. The mean temperature also follows an increasing trend, for the last two decades, with an increment of $0.011{ }^{\circ} \mathrm{C}$ per year. All of these results suggest an overall warming due to increase in maximum temperature and slight decline inthe decreasing trend of minimum temperature in the recent decades.

In case of seasonal trend, it is observed that both the maximum and minimum pre-monsoon temperatures are increasing by a gradient of $0.007{ }^{\circ} \mathrm{C}$ and $0.023^{\circ} \mathrm{C}$ per year, respectively (Fig.6a). However, during monsoon season, the maximum temperature is on a declining trend with a gradient of $0.003{ }^{\circ} \mathrm{C}$ per year. Unlike this, the minimum temperature is increasing slightly with a gradient of $0.008{ }^{\circ} \mathrm{C}$ per year (Fig.6b). Similarly both maximum and minimum temperature trends tend to follow a decreasing trend during the post monsoon season (Fig. 6c). Finally, during the winter season, the maximum temperature 
is observed to be decreasing with a gradient of $0.013{ }^{\circ} \mathrm{C}$ whereas the minimum temperature is increasing with an increment of $0.015^{\circ} \mathrm{C}$ per year (Fig. $6 \mathrm{~d}$ ).

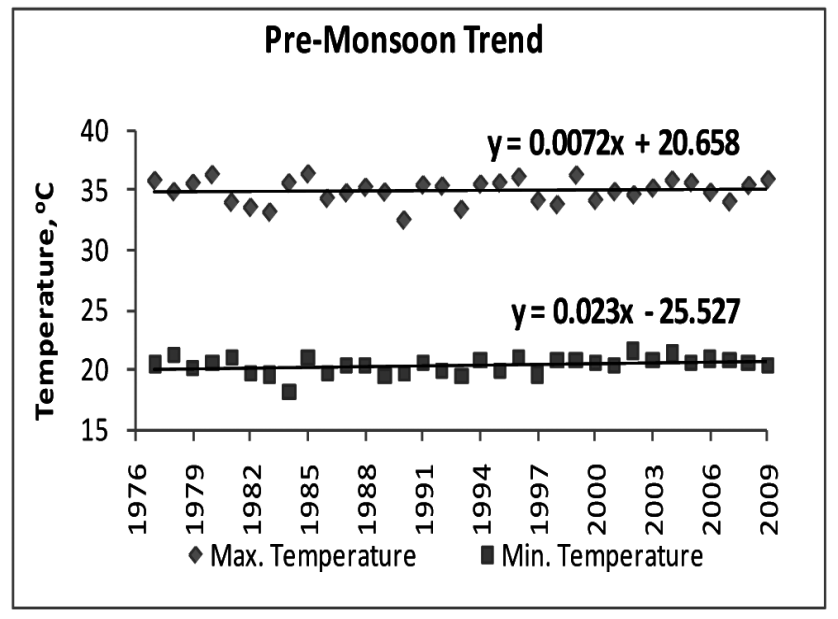

Fig. 6a. Temperature trends during pre-monsoon seasons for the years $1976-2009$

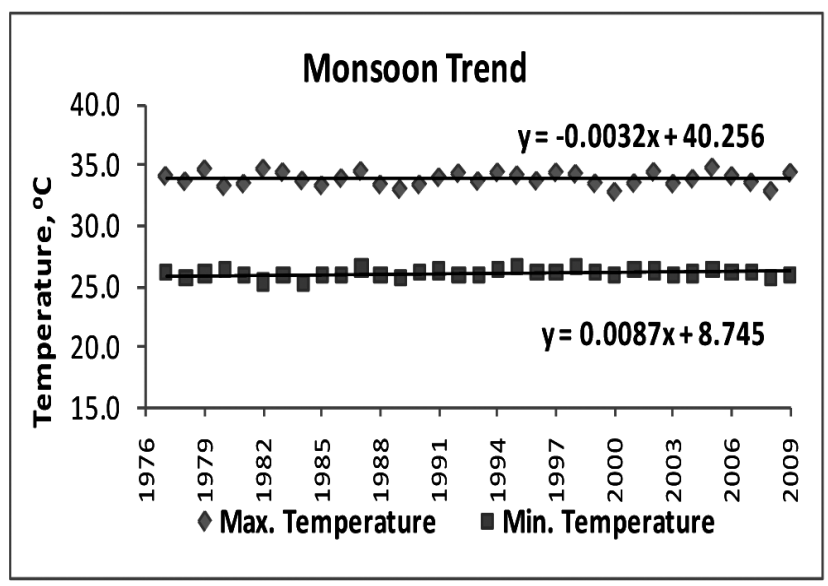

Fig. 6b. Temperature trends in monsoon seasons for the year 1976 - 2009

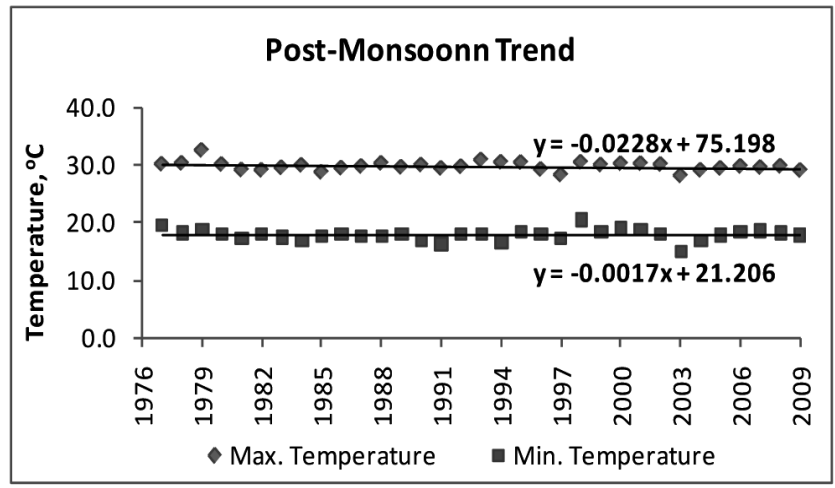

Fig. 6c. Temperature trends in post-monsoon seasons for the years $1976-2009$

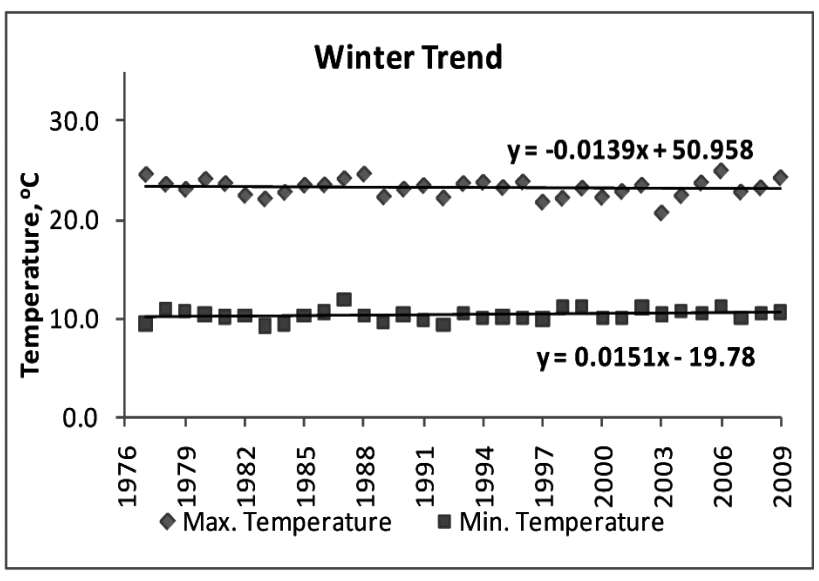

Fig. 6d. Temperature trends in winter seasons for the years 1976 - 2009

\section{Precipitation trends}

The precipitation data from 1976 to 2012 were used for the trend analysis, which included the followings:

i) Annual precipitation trend (Fig. 7 );

ii) Monsoon precipitation trend (Fig. 8 ); and

iii) Extreme rainfall trend (Fig. 9).

Although there is no any significant trend in each of the components (annual, monsoon and extreme events) of the precipitation, it seems, generally, that the annul precipitation as well as the monsoon precipitation is in declining trend, though not remarkable (Fig.7, 8 and 9). Similar situation is existed in the case of extreme rainfall events as well. However, a remarkable features observed in each of the three cases is that their trend is gradually increasing for the last decade (2002 - 2012), except the years 2001 and 2007 for which data are not available.

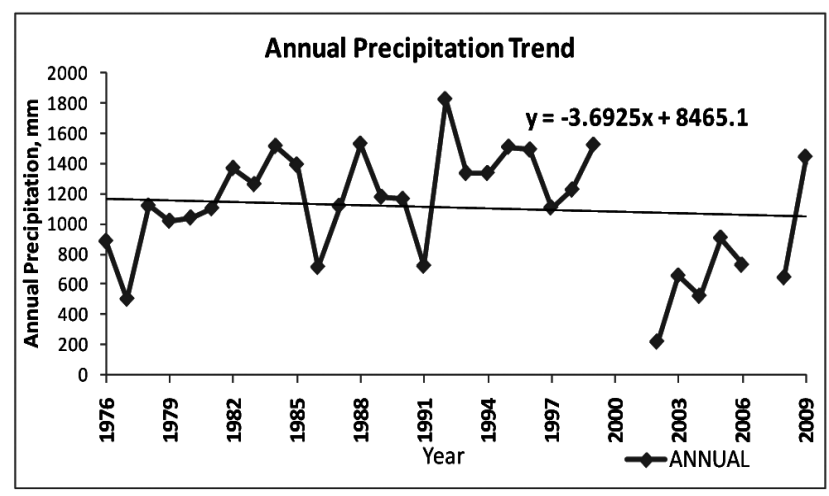

Fig. 7. Annual precipitation trends for the years 1976 - 2012 (data are not available for the years 2001 and 2007) 


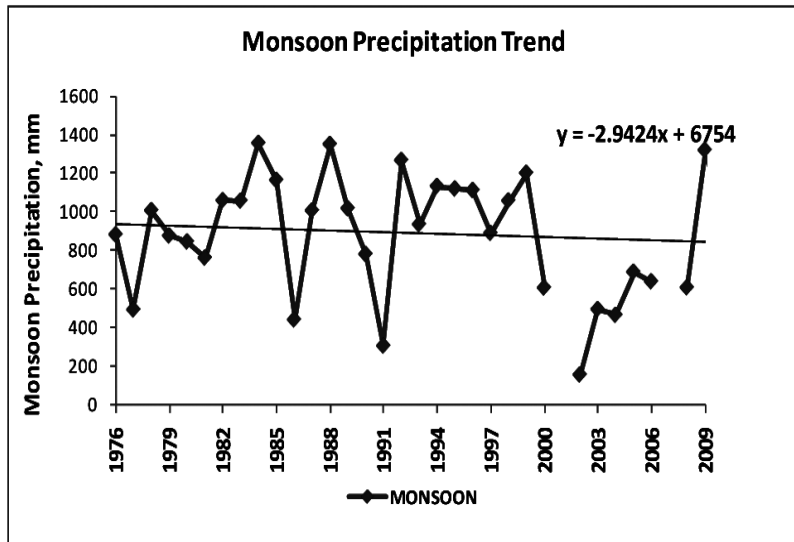

Fig. 8. Monsoon precipitation trends for the years 1976 - 2012 (data are not available for the years 2001 and 2007)

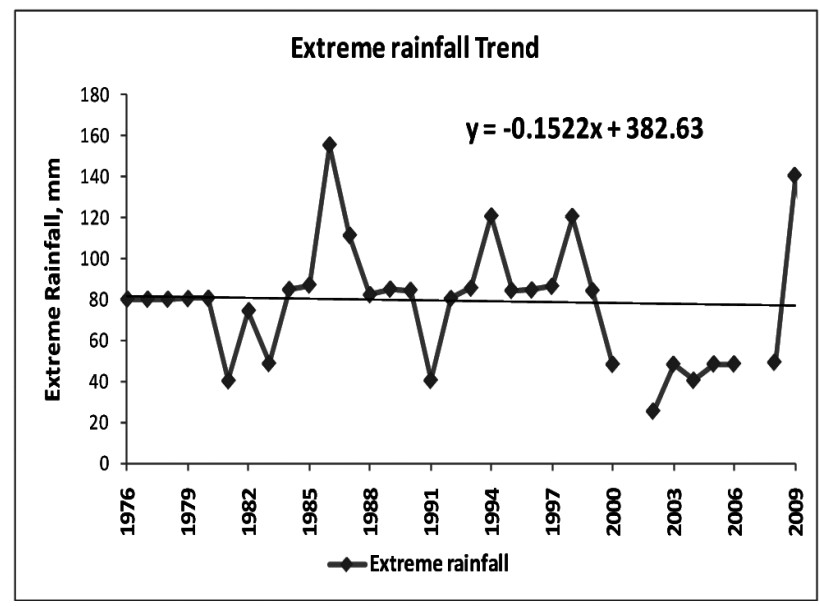

Fig. 9. Extreme rainfall trend for the years 1976 - 2012 (data are not available for the years 2001 and 2007)

\section{River dynamics}

The Dhondra River is a seasonal stream originated in the northern most part of the Siwalik range. The river takes its course almost north-east to south-west within the hilly areas and northern part of the Terai. Onward, especially near the damaged site, it flows almost east-west until it converses with the East Rapti River (the main drainage of the area) in the Middle Terai. In fact, as suggested by the local people, the Dhondra River channel was limited only up to the eastern part of the Dhondra village until around1950 indicating that the river discharge was not huge and the river water was infiltrating down completely through the porous river channel at that time. Its channel was extended up to the East Rapti River just around 1960 due to an extreme flood event that caused sudden increase in river discharges significantly. Then onward, the river was gradually shifting westward in each Monsoon floods. The Dhondra River and the Shinghya River were about $3 \mathrm{~km}$ apart at their confluence with the East Rapti River prior to the flooding event of 1995 . In 2000, the Dhondra River suddenly shifted remarkably westward and blockaded the flow of Shinghya River, a tributary of the East Rapti River.

\section{Land use and inhabitants}

The Siwalik hill range, in the study area, is covered with thick forest, whereas the Terai is basically cultivated land with scattered villages. In some parts of the Terai, particularly in the Bhabher zone, there exist forest lands, where bushes are predominant comparing to the situation of tall trees. Grazing lands, fallow lands (left uncultivated due to sediment deposition and drought) and river side terraces form the other types of land use in the area. The majority of the inhabitants of the area are native people, known as Yadab, and the migrated people, of different casts and ethnic groups, are insignificant. Agriculture and livestock are the main source of livelihood.

\section{Geo-environment degradation}

Ward $5 \& 6$ of Gangapur VDC was inundated due to the blockade of the Singhya River by the sediments brought by the Dhondra River in 2000 (Fig. 10). Consequently, about 305 families were completely displaced due to the inundation in and around their home and farmlands. After 2000, the Dhondra River started depositing sandy sediments in and around the confluence point during each monsoon floods. As a result, cultivated lands on either side of the Singhiya River were further inundated. It was also observed that almost all the displaced families illegally encroached the nearby forest land to build residential huts. Besides, they started illegally cutting trees in the forest to sale in the nearby markets as a means of livelihood. In addition, they also initiated excavation of rocks in the river bed (rock exposures forming natural check dams across the river bed, Fig. 2) and river banks, especially along the Dondra River, as a means of producing construction materials to be sold in nearby cities. Further, their cattle such as goats, buffaloes, cows and oxen were also taken to the forest for grazing. These activities have resulted deforestation, soil erosion in forest and graze lands, bed and bank erosion along the Dhondra River, sheet erosion on the deforested land, flash floods in seasonal streams causing sedimentation on cultivated land, increase sediment load in river waters, and drying out of springs and water sources. 


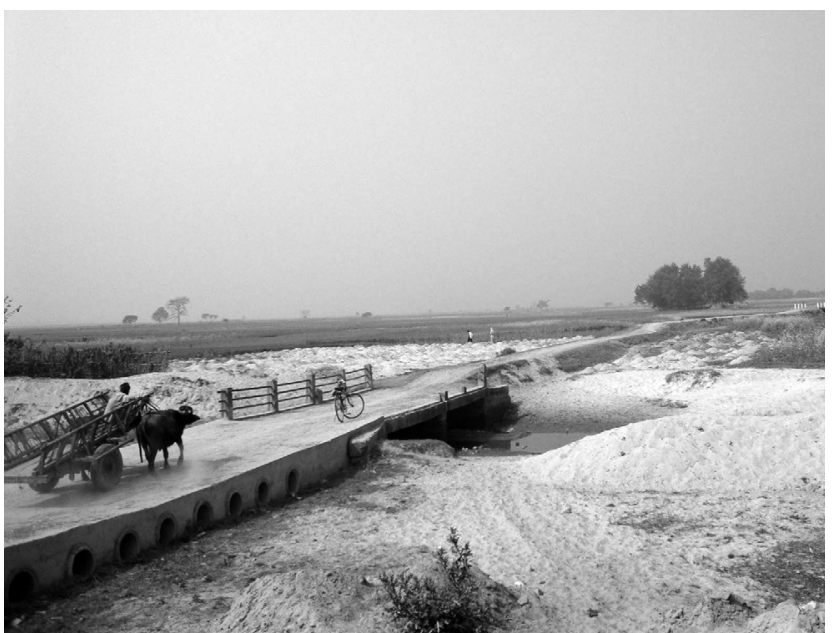

Fig. 10. Sand deposited by the Dhondra River at the confluence with the Singhya River. Notice the bridge pillars are almost covered by the sand deposition

\section{DISCUSSIONS}

According to a report by MoENV (2010), the temperature trends in Nepal for the period of 1971-1994 have indicated a continuous warming at an average annual rate of $0.06{ }^{\circ} \mathrm{C}$ which varied spatially as well as seasonally. The pre-monsoon season (March-May) has showed the lowest warming rate of $0.03{ }^{\circ} \mathrm{C} / \mathrm{yr}$, while the postmonsoon season (Oct.-Nov.) has showed the highest one of $0.08^{\circ} \mathrm{C} / \mathrm{yr}$. Warming rate is higher in the northern part than that of the southern part of the country. In case of precipitation, the same report highlights a fact that there is no rainfall change in western part and up to $5-10 \%$ increase in eastern Nepal for winter. During the summer months precipitations are projected to increase for the whole country in the range of 15 to $20 \%$.

Almost similar results are obtained from the study site. An analysis of temperature data recorded from 1976 to 2009 has suggested an overall warming due to increase in maximum temperature $\left(0.032^{\circ} \mathrm{cv}\right.$ per year $)$ and slight decline in the minimum temperature $\left(0.008^{\circ} \mathrm{C}\right.$ per year $)$ in the later decades, starting form 1986 . Since the study site belongs in the southern part of the country, the increase in temperature, though not much significant, is in line with the warming scenario as mentioned in the National Adaptation Plan of Action report (MoENV, 2010).

Although the overall average precipitation trend during the years $1976-2012$ is not significant, the last decade (2002 -2012) has experienced a significant increasing trend in annual and monsoon precipitation and extreme events. These facts clearly indicate that the area is under the influence of climate change, which has resulted a slight increase in mean and maximum decadal temperature particularly since last three decades, and also increase in annual, monsoon and extreme events of precipitation. The sudden flood occurred in the Dhondra River in 2002 due to localized intense precipitation can therefore be considered as a part of the impact of climate change in that region.

Since the High Mountains block the monsoon passing into central Asia, precipitation is highest in front of the Higher Himalayan range. Intense precipitation also occurs in the areas lying south of the High Mountain regions including Middle Mountain, Siwalik, and Terai. This results high discharge in the rivers and streams originated in these mountain ranges. The Dhondra River is one of the seasonal streams of this kind originated in the Siwalik hills. The intense precipitation events in the monsoon season give rise high discharge which flows with high velocity owing to the steep river bed gradient (Fig. 11) in the Siwalik zone. As soon as the river water emerges in the Terai plain, the velocity reduces significantly due to low river bed gradient. Consequently, coarser sediments start depositing, causing river bed rise. This situation has promoted flooding as the river depth becomes shallow and discharge spills over the banks in the Terai region. This process seems to be responsible for the shifting of the Dondra River channel westward since 1995. After 1995, intense and localized precipitation started occurring, as an impact of climate change in that region, in its catchment almost each year resulting huge discharge in the river. It promoted even bigger flooding events than before, and shifting of the river channel westward was also accompanied faster accordingly. In the flooding event of 2000 , owing to the huge sediment-loaded discharge, the river channel shifted further westward blocking the Shinghya River, whose discharge was comparatively less due to almost no rainfall in its upper catchment. It means the area suffered with localized intense precipitations. After 2000, as the natural check dams created by rock exposures across the river are being excavated along with removing the big boulders scattered along the river bed by local people, river is transporting all the sediments directly to the lower reaches of the river. Deforestation and grazing also promoted soil and rill erosions increasing sediment load in the river water. This process is responsible for depositing huge amount of sands each year around the confluence point with the Singhya River. 


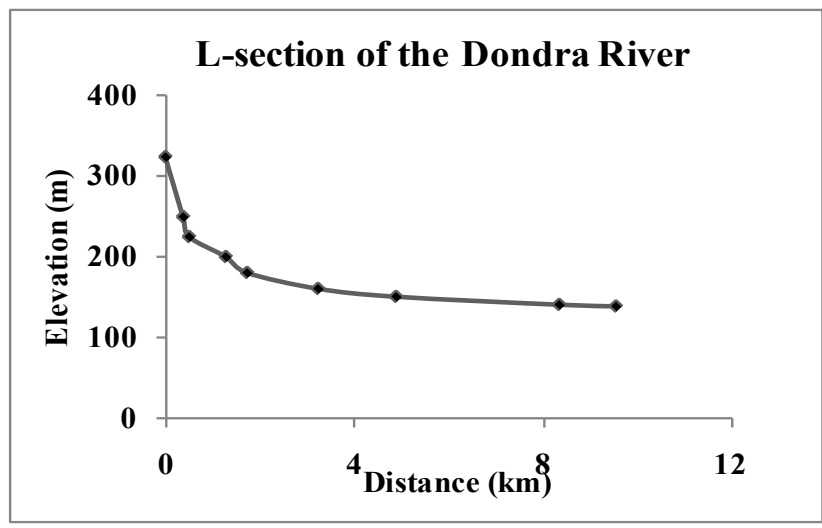

Fig. 11. Longitudinal section of the Dhondra River

The above mentioned impacts may be minimized by afforestation and forest conservation in sediment production zone, managing graze land properly, prohibiting rock excavation along river beds and banks, introducing alternative source of livelihood to the effected families, constructing check dams across the river channel (in sediment transportation zone), and building embankments (in sediment deposition zone) on either side of the river in the Terai plane.

\section{CONCLUSIONS}

The climate change outcome risks in Dhondra River watershed included floods, sedimentation in cultivated lands, deforestation, intense river bank and bed erosion, and forced-migration of local people. These risks are the accumulated impacts of climate change which has been significantly observed in the Dhondra River watershed since last three decades. Although the investigation was limited within a comparatively small watershed, this result forms an example of climate-induced disaster in the southern slope of the Siwalik and northern part of the Terai. For a more concise explanation on the impact of climate change on the foothill of the Siwalik, further researches are required covering eastern, central and western part of Nepal.

\section{ACKNOWLEDGEMENT}

The author is very much grateful to two unanimous reviewers for their constructive suggestions and valuable inputs to improve the manuscript. The author also would like to acknowledge the suggestions and inputs received from Dr. Rabindra Osti, International Centre for Water Hazard \& Risk Management under the auspices of UNESCO (ICHARM), Japan during the field visit.
Similarly, the author is also thankful to Mr. Dhiraj Gyawali, Nepal Development Research Institute (NDRI) for providing valuable insights to analyze the climate data.

\section{REFERENCES}

Devkota, D.C. and Bhattarai, T.N. 2011. Impact of climate change and possible strategic programs for building climate resilient communities in Nepal. Journal of Nepal Geological Society 43: 219-224.

Bhattarai, T.N. 2012. State of climate change and its impact in Nepal. In: Climate Change and UNFCCC Negotiation Process. (eds.) Devkota, D.C., Uprety, B.K. and Bhattarai, T.N. Ministry of Environment, Science and Technology (MoEST), Government of Nepal, Kathmandu, Nepal. 13$28 \mathrm{p}$.

Gansser, A. 1964. Geology of the Himalaya. Interscience Publishers, 289p.

Joshi, J., Bhattarai, T.N., Sthapit, K.M. and Omura H. 1998. Soil erosion and sediment disaster in Nepal-a review. Journal of Faculty of Agriculture, Kyushu University 42 (3 \& 4): 491-502.

Ministry of Environment (MoENV). 2010. National Adaption Program of Action (NAPA), Ministry of Environment, Government of Nepal, Kathamndu.77p.

Sharma, C.K. 1990.Geology of Nepal Himalaya and adjacent countries. Sangeeta Sharma, Kathmandu, 479p.

Upreti, B.N. 2001. The physiography and geology of Nepal and their bearing on the landslide problem. In: Landslide Hazard Mitigation. (eds.) Tianchi, L., Chalise, S.R. and Upreti, B.N. International Centre for Integrated Mountain Development (ICIMOD), Kathmandu, Nepal. 31-50p.

Water and Energy Commission Secretariat (WECS). 2005. National Water Plan (2002-2027). Water and Energy Commission Secretariat, Government of Nepal, Kathmandu. 97p.

Land Resources Mapping Project (LRMP). 1986. Land Systems Map of Nepal. Topographical Survey Branch, Survey Department, Ministry of Land Reforms, Government of Nepal, Kathmandu. 